\title{
A VIRTUOUS CIRCLE: ACADEMIC EXPERTISE AND PUBLIC PHILOSOPHY
}

\author{
AARON JAMES WENDLAND
}

\begin{abstract}
This essay examines the relationship between academic and public philosophy through the lens of Heidegger studies. Specifically, this essay: shows how Heidegger uses technical terminology within the context of the academy to break new philosophical ground; explains how suitably clarified technical terminology can be used to introduce people to Heidegger's philosophy and to apply Heidegger's ideas to current affairs; and illustrates how the application of Heidegger's ideas to contemporary issues results in new forms of academic research. Ultimately, this essay argues that there is a dialectical relationship between academic and public philosophy: i.e., public philosophy translates esoteric ideas developed in the academy into publicly accessible prose and then applies those ideas to daily life; but in doing so, public philosophy inspires new lines of academic inquiry.
\end{abstract}

Key words: knowledge; expertise, technical terminology; education; current affairs; Heidegger; metaphilosophy.

In a famous essay published in the early-1930s, Rudolf Carnap accused Martin Heidegger of producing a great deal of nonsense, and any lay person who picks up Heidegger's books today is likely to perceive Heidegger's work in much the same way. ${ }^{1}$ Of course, Heidegger bears some responsibility for this perception. His writings presuppose a reader who is familiar with subtle and difficult debates in the history of philosophy, and Heidegger only makes matters worse through his willingness to use old words in new ways and through his penchant for coining a new phrase. With that said, I begin this essay by illustrating the philosophical utility of Heidegger's so-called 'nonsense'. Specifically, I explain how Heidegger's unorthodox use of 'Dasein' and his invention of new terms like 'Gestell' and 'Bestand' enable him to break new philosophical ground. I then go on to indicate the pedagogical and practical value of translating Heidegger's arcane writing into publicly accessible prose by showing how suitably clarified technical terminology can be used to both share philosophical insight with non-specialists and elucidate current affairs. Finally, I highlight the dialectical relation between academic expertise and public philosophy.

1 To be fair, Carnap's technical account of 'nonsense' as a violation of logical syntax would likely strike the lay person as nonsense, too. See Carnap (1978, pp. 23-34). 
Particularly, I show how using academic understanding to analyze current events can inspire new forms of academic research.

\section{The Technical Terminology of Academic Philosophy}

Heidegger's stated aim in Being and Time is to "work out the question of the meaning of Being." (Heidegger, 1962, p. 19, §1). He does so through a detailed analysis of Dasein. 'Dasein' is an ordinary German word that means 'existence'. Yet in Being and Time, Heidegger uses 'Dasein' as a technical term for 'human being' to make a series of subtle philosophical points. First, Heidegger uses 'Dasein' for 'human being' to indicate the connection between being (Sein) and human being (Dasein). In doing so, he paves the way for his claim that the being of an entity, say, that and what a hammer is, is determined by a distinctly human way of being, in this case, carpentry. Second, the link between 'Dasein' and 'existence' allows Heidegger (1962) to push back against notions of a fixed human nature and assert that "the 'essence' of Dasein lies in its existence" (p. 67, §42). This means who and what we are is tied to a contingent set of circumstances and we are always free to change our identity from, say, being a carpenter to serving as a teacher. Lastly, Heidegger exploits the literal meaning of 'Da-sein' as 'there-being' to question the modern account of humans as self-sufficient subjects that stand over and against independent objects and instead suggests that the identity of humans is bound up with their surroundings. Being a carpenter, for instance, requires using a certain set of tools and immersing oneself in the practices and rules that characterize a carpenter's work-environment. Taken together, Heidegger's unorthodox use of 'Dasein' as a technical term for 'human being' allows him to circumvent misunderstandings that come when words like 'essence' and 'subject' are applied to humans, and it helps him demonstrate that the being of entities is determined by the various ways humans exist in the world around them. ${ }^{2}$

In The Question Concerning Technology, Heidegger offers a socio-historical account of being that both broadens and deepens the interpretation of being he developed in Being and Time. Specifically, that and what a hammer is is not simply determined by the activity of a carpenter in a particular work-environment but depends upon a background 'destining of being' that sets a general standard for the way entities appear in a given epoch (Heidegger, 1977, p. 26). Briefly, humans have different background assumptions about the fundamental nature of reality at different points in history, and Hubert Dreyfus illustrates the way these disparate assumptions affect the appearance of entities when he writes:

The Greeks encountered things in their beauty and power, and people as poets, statesman, and heroes; the Christians encountered creatures to be catalogued and used appropriately and people as saints and sinners; and we moderns encounter objects to be controlled and organized by subjects in order to satisfy their desires. (Dreyfus, 1991, p. 338)

Since a 'destining of being' is the background that enables entities to appear in the foreground, it is difficult to describe using the language we typically apply to entities. So, Heidegger coins two new words to articulate the assumptions that determine the way entities

2 For a detailed account of Heidegger's technical use of 'Dasein', see Carman (2003, pp. 35-43). 
are presented in the modern world: 'Gestell' and 'Bestand'. Gestell is often translated as 'enframing' or 'positionality', whereas Bestand is rendered as 'stock' or 'resource'. And Heidegger uses these technical terms to show how our current techno-scientific assumptions frame, position, and ultimately enable us to see the world as a stock of resources. In sum, Heidegger develops an account of 'Dasein' in Being and Time to illustrate that the 'being' of a hammer is determined by the activity of carpentry. But in The Question Concerning Technology, Heidegger writes about 'Gestell' and 'Bestand' to demonstrate that the activity of carpentry is itself based on a deeper and broader 'destining of being' that presents our surroundings as resources to be used for production and consumption. ${ }^{3}$

Although Heidegger's use of Dasein, Gestell, and Bestand may make little sense to nonspecialists, these technical terms serve a philosophical purpose. As we've seen, Heidegger uses 'Dasein' to indicate the connection between 'being' and 'human being', show that the essence of 'human beings' lies in their 'existence', and highlight the fact that 'human beings' are 'there-being', i.e., that they cannot be separated from their surroundings. In each case, Heidegger employs 'Dasein' to overcome certain problems built into earlier technical terminology, say, the skepticism that follows from characterizing humans as 'subjects' who are separated from 'objects'. ${ }^{4}$ And by addressing these philosophical issues, Heidegger offers a clearer and more accurate picture of what it means to be a human being. Similarly, Heidegger breaks new philosophical ground by using 'Gestell' and 'Bestand' to tease out the background assumptions that guide our modern technological way of life. And like all academic jargon, Heidegger's seemingly nonsensical use of Dasein, Gestell, and Bestand is designed to provide specialists with a deeper understanding of the phenomenon they are studying.

\section{Academic Philosophy and Public Accessibility}

Heidegger's academic work breaks new ground by building on and responding to the writings of key figures in the history of philosophy, including Plato, Aristotle, Kant, Kierkegaard, Nietzsche, and Husserl. In fact, it is Heidegger's mastery of the fine distinctions, detailed argumentation, and abstruse jargon of previous academic philosophy that allows him to use Dasein, Gestell, and Bestand in innovative ways to enhance our understanding in metaphysics, epistemology, existentialism, and phenomenology. Yet the awareness Heidegger achieves via his critical engagement with the history of philosophy and novel vocabulary comes at a cost: appreciating his ingenious work requires a great deal of philosophical expertise. And if Heidegger's insight into the existence of human beings and our technologically driven societies is to have an impact beyond the academy, then his terminology needs to be translated into a language the lay person understands.

The best way to turn academic jargon into publicly accessible prose is by offering concrete examples of the phenomena under consideration. Take the connection Heidegger

3 For a detailed account of Heidegger's philosophy of technology, see (Wendland, Merwin, \& Hadjioannou, 2019).

${ }_{4}$ For Heidegger's critique of the subject-object dualism that leads to skepticism about the existence of the external world, see Heidegger 1962, pp. 246-252, §202-208. 
sees between 'being' and 'human being' that motivates his use of 'Dasein'. According to Heidegger (1962), "being 'is' not itself an entity" but "that which determines entities as entities" (pp. 25-6, §6). Here we have a rather abstract account of the relation between being and entities. But the idea can be rendered concrete if we focus on a particular entity and the way being determines its identity. In Being and Time, Heidegger (1962) explains how the identity of a hammer is defined by its relation to nails, tape-measures, skill-saws, and other items in a given work-environment. Specifically, the identity of a hammer is determined by driving nails into suitably measured and skillfully cut pieces of wood in order to build a house (pp. 95-102, §67-2). This suggests that the being of a hammer, i.e., that and what a hammer is, is defined by a set of purposive relations between disparate entities in a specific context. Yet Heidegger (1962) is quick to point out that the purposive relations between hammers, nails, tape-measures, and skill-saws is relative to a particular human activity: carpentry. This means: "Only as long as Dasein is [. . .] 'is there' Being” (p. 255, §212). So, the being of a hammer is ultimately defined by the way a carpenter uses it along with other tools to construct a home. And with this concrete example in place, we see that Heidegger's abstract account of the connection between 'being' and 'human being' indicates the way particular human activities determine the identity of specific entities.

Describing particular instances of a general theme is also an effective approach to explicating the technical terms in Heidegger's philosophy of technology. Recall, Gestell is Heidegger's word for the way our techno-scientific assumptions about reality enable us to treat our surroundings as Bestand: i.e., as a stock of resources for production and consumption. Heidegger (1999) unpacks this general idea by describing the mathematical models we use to measure, manipulate, and control our environment to satisfy our ends. "Calculation," he claims, aims at "certainty in governing and planning" (p. 98). And by transforming our surroundings into calculable bits matter, he says, "the earth and its atmosphere become raw material for self-assertive production." (Heidegger, 1971, p. 109). Yet we can really see what Heidegger means if we return to the particular case of carpentry. To carry out the task of building a home, carpenters rely on various resources and the technical skill required to mine and manufacture them. Foresters convert timber into plywood, engineers transform rivers into hydroelectricity, and metallurgists and machinists turn iron ore into hammers, tape-measures, and other such tools. In each instance, the application of techno-scientific assumptions to the natural world reduces it to a resource that carpenters can use at their disposal. But Heidegger (1977) is keen to show that we use mathematical modeling to reduce ourselves to resources, too (pp. 18, 101). Carpenters, after all, are part of a labor market, and their skills are regularly quantified by economists who use statistical analysis to try and boost GDP. Here we see the force of Heidegger's claim that both the activity of carpentry and the identity of a hammer are determined by a deeper and broader destining of being that presents our surroundings as a stock of resources. And after offering tangible examples of Gestell and Bestand, we have a clearer picture of the background assumptions that direct our techno-scientific way of life.

When we combine Heidegger's account of the connection between 'being' and 'human being' with his analysis of the 'destining of being' that governs our technological age, we are presented with an image of modernity in which purposive human activity reduces reality to resources for production and consumption. Heidegger develops this image by 
engaging with the history of philosophy and employing a new vocabulary. But the technical terminology he uses to increase human knowledge within the context of the academy may seem like nonsense to non-specialists. So, Heidegger's insight into human existence and techno-science has to be translated into a language lay people comprehend to ensure it has an impact on human understanding writ large. This translation is achieved by taking Heidegger's abstract discussions of Dasein, Gestell, and Bestand and making them concrete. Specifically, Heidegger's jargon can be turned into accessible prose by offering particular examples of the general phenomena he describes. Dasein indicates the link between 'being' and 'human being', and we can see this connection if we explain the way the identity of a hammer is determined by a human activity: carpentry. Likewise, Gestell and Bestand refer to the way techno-science reduces the world to resources, and this concept is clear enough if we describe how engineers use mathematical models to turn rivers into hydroelectricity. In each of these cases, a technical term is extracted from the subtle distinctions and detailed argumentation required to develop and defend an idea in the academy. It is then translated into ordinary language by illustrating the key idea through a tangible example. And once a technical term is converted into a conventional idiom, a novel academic idea can be shared with non-specialists. In short, turning Heidegger's arcane academic writing into publicly accessible text serves a pedagogical purpose by allowing Heidegger's insights to be introduced to everyone.

\section{Public Accessibility and Applied Philosophy}

After Heidegger's ideas have been translated from the technical terminology of the academy into publicly accessible text, they can be used to clarify and analyze current events. Doing this requires academic expertise and the ability to turn jargon into a common vocabulary. But it also demands paying close attention to public debate as well as a willingness to engage with people beyond the university. Heidegger, for his part, thought the power of modern techno-science created a crisis for humanity. In fact, he believed reducing the world to resources to satisfy our ends led to a loss of the sacred, the violation of nature, and the destruction of our home. And he argued that we need to break free from our self-serving use of technology to overcome the crisis of modernity. ${ }^{5}$ Of course, Heidegger did not live to see the melting sea ice, mass extinctions, and plastic contamination of the $21^{\text {st }}$ Century. However, his account of Gestell and Bestand can help us understand the climate crisis. ${ }^{6}$ Grasping the depth of Dasein's freedom is equally key to confronting the climate emergency. And connecting Heidegger's views on modern technology and human freedom with the climate crisis will enable us to see the practical value of turning Heidegger's jargon into ordinary language and then applying it to current affairs.

According to Heidegger, our modern technological destining of being emerged with the scientific revolution in the $17^{\text {th }}$ Century, and its background assumptions are embodied in Descartes' belief that advances in mathematics will make us "masters and possessors of nature" (Descartes, 1998, p. 35). Heidegger (1977) acknowledges the material benefits we

5 For a detailed defense of this reading of Heidegger's philosophy of technology, see Young (2002).

6 See, for example, Wendland (2019a). 
have acquired through modern science, but he thinks our self-serving use of science and technology leads to the sacrilege, violence, and destruction that characterize modernity and thus our current climate emergency (pp. 3-35). Briefly, Heidegger sees the life-sustaining power of nature as worthy of respect and thus a check on our self-assertion. ${ }^{7}$ Yet our modern attempt to manipulate and control the world means we have lost our sense of a sacred natural order. Ironically, violating the natural order by turning the world into desire-satisfying resources results in the destruction of our home. When we engage in factory farming, clearcutting, or dam-building, we violate the natural state of pheasants, fir trees, and estuaries. And when we reduce nature to resources in this way, we effectively destroy the ecosystems upon which human life depends. Although environmental degradation and the destruction of our habitat are clearly concerning, Heidegger is also worried about the impact of technoscience on human freedom. In fact, Heidegger (1977) believes we have become so enthralled with the apparent success of science and technology that we have a hard time imagining an alternative way of living (p. 27). This suggests responding to the climate emergency involves twisting ourselves free from our self-serving and uncritical use of technology. And if Heidegger's description of Gestell and Bestand can help us see the techno-scientific source of our climate crisis, his depiction of Dasein's freedom paves the way for a different destining of being.

As noted above, 'Dasein' is an ordinary German word that means 'existence', but Heidegger uses it as a technical term for 'human being' to indicate that the essence of human beings lies in their existence. This means who and what we are is tied to a contingent a set of circumstances and we are always free to change our identity. In the $21^{\text {st }}$ Century, human identities are calculated to fit within a broader system of production and consumption. Professionally, our skills are seen as resources to be used by employers and policy makers, and our ability to be carpenters, teachers, or engineers is subject to the dictates of the market. Personally, our news, entertainment, friendships, and familial duties are increasingly driven by algorithms that collect our data and sell it to companies seeking to bolster their bottom line. And even our recreational time has been quantified to the point that it is unclear if we are running for our well-being or the Strava app. Here we see human identities shaped by the techno-scientific mastery that has led to our climate emergency. Yet the fact that our identities are contingent and open to change suggests that we can free ourselves from our technological destining of being. Heidegger (2010) believes this freedom is achieved via a form of 'willful non-willing' that releases us from our self-assertive activities and puts us in a position to interact with nature in a sustainable way (pp. 33-43). Of course, 'willful nonwilling' sounds contradictory, but the basic idea is clear: we need to resist our tendency to reduce the natural world to a resource we use to satisfy our own ends. And this resistance is exemplified by Greta Thunberg's school strikes as well as the various protests led by Extinction Rebellion, Green Peace, and other environmental groups. In sum, the fact that "the 'essence' of Dasein lies in its existence" (Heidegger, 1962, p. 67, §42) implies that we are free to change our identity and using this freedom to adopt an alternative way of life is crucial to confronting the climate crisis.

\footnotetext{
7 See Heidegger's account of poiesis at Heidegger (1977, pp. 15-16).
} 
Drawing on Gestell and Bestand to analyze our climate emergency illustrates the extent to which our attempt to quantify and control our surroundings leads to a loss of the sacred, the violation of nature, and the destruction of our home. Discussing Dasein also shows that we are free to change our identity and therefore open to interacting with nature in a sustainable way. And applying Heidegger's account of modern technology and human freedom to the climate crisis is a valuable addition to public discourse insofar as it points to the self-assertive source of environmental degradation and suggests we need to check our desire to master the natural world. Here we see the practical benefit of turning Heidegger's technical terminology into a common vocabulary and then applying it to current affairs: it allows us makes sense of our contemporary predicament and it provides us with the insight we need to make educated decisions. Of course, contributing to public discourse on climate change is likely to raise questions and provoke replies from citizens across the political spectrum. This means applying Heidegger's ideas to current issues requires academic expertise, a penchant for public writing, and a willingness to engage with a wide variety of people. Ideally, this public debate will put Heidegger's philosophy of technology to the test and simultaneously result in an informed citizenry. And ultimately, employing Heidegger's depictions of Gestell, Bestand, and Dasein to analyze the climate crisis is designed to help us determine the best way to sustain life on this planet. ${ }^{8}$

\section{Applied Philosophy and the Academy}

On a Heideggerian reading, confronting the climate crisis involves cultivating an alternative to the techno-scientific destining of being that has governed our interaction with nature since the $17^{\text {th }}$ Century. The first step in this process is resisting our tendency to reduce the world to resources. Yet this resistance is just the beginning, and real creative work needs to be done to imagine a different way of living. At the very least, a viable alternative to our self-assertive and technologically driven societies will have to protect the integrity of our life-sustaining ecosystems. Heidegger (1992) accordingly speaks of 'letting things be' and he asks us to shift our mindset from 'masters and possessors of nature' to 'shepherds of being' (p. 234). The notion of shepherding suggests we need to both preserve the natural world and ensure our own well-being. But figuring out how to strike this balance will demand a great deal of research in nearly every area of human inquiry. To date, Heidegger scholars have used his work to develop deep ecology and ecofeminism. ' And just as Heidegger utilized 'Dasein', 'Gestell', and 'Bestand' to break new philosophical ground, environmental ethicists employ technical terms like 'biocentrism', 'de-growth', and 'sentientism' to challenge existent anthropocentric moral theories and to increase our understanding of the world, generally. ${ }^{10}$ Now whether ecofeminism or biocentrism will result in a new destining of being is an open

\footnotetext{
8 For readers who have doubts about the practical value of Heidegger's philosophy due to his decision to join the Nazis, see Wendland (2019b).

9 For an overview of Heidegger's influence on the deep ecology movement, see Zimmerman (2019). For an example of Heidegger's applicability to ecofeminism, see Claxton (2017).

${ }^{10}$ For an overview of key terms in the growing sub-discipline of environmental ethics, see Attfield (2018).
} 
question. But one thing is clear: translating Heidegger's academic jargon into publicly accessible text and then applying it to our current climate emergency has inspired new forms of academic research.

And with that, we have come full circle. Heidegger uses Dasein, Gestell, and Bestand as technical terms in his academic writing to make a series of subtle philosophical points and ultimately advance our understanding in metaphysics, epistemology, existentialism, and phenomenology. Yet Heidegger's ability to push the boundaries of human inquiry presupposes a certain mastery of the fine distinctions, detailed argumentation, and arcane jargon of previous academic philosophy. This means appreciating Heidegger's insight into human existence and our techno-scientific societies requires a great deal of philosophical expertise. And if Heidegger's ideas are to have any influence beyond the academy, his vocabulary needs to be translated into a language the lay person comprehends. This is achieved by offering examples that illustrate ideas unearthed via words like Dasein, Gestell, and Bestand. And once technical terms are converted into a common idiom, novel academic ideas can be shared with non-specialists and used to analyze current affairs. This suggests there is pedagogical and practical value to be had by turning Heidegger's academic 'nonsense' into publicly accessible text. Specifically, suitably translated technical terminology can be used to both introduce curious people to philosophy and contribute to public debate over the most pressing issues of our time. That said, there is a dialectical relation between academic and public philosophy insofar as the application of academic ideas to current issues elicits questions that require new forms of research. And in the end, academic and public philosophy prove their worth through the impact they have on education, human understanding, and how we lead our lives.

\section{References}

Attfield, R. (2018). Environmental ethics. Oxford: Oxford University Press.

Carman, T. (2003). Heidegger's analytic. Cambridge: Cambridge University Press.

Carnap, R. (1978). The elimination of metaphysics through the logical analysis of language. In M. Murray (Ed.), Heidegger and modern philosophy: Critical essays (p. 23-34). New Haven: Yale University Press.

Claxton, S. (2017). Heidegger's Gods: An ecofeminist perspective. London: Rowman and Littlefield.

Descartes, R. (1998). Discourse on Method. Tr. Cress. Indianapolis, Hackett. (Original work published 1637).

Dreyfus, H. (1991). Being-in-the-world. Cambridge: MIT Press.

Heidegger, M. (1962). Being and time. (J. Macquarrie \& E.S. Robinson, Trans). New York: Harper \& Row.

Heidegger, M. (1971). Poetry, language, thought. (A. Hofstadter, Trans.). New York: Harper \& Row.

Heidegger, M. (1977). The question concerning technology. (W. Lovitt, Trans.). New York: Harper \& Row.

Heidegger. M. (1992). Basic writings. (D.F. Krell, Trans). New York: HarperCollins.

Heidegger, M. (1999). Contributions to philosophy. (P. Emad \& K. Maly, Trans.). Bloomington: Indiana University Press.

Heidegger, M. (2010). Country path conversations. (B.W. Davis, Trans.). Indianapolis: Indianapolis University Press. 
Wendland, A.J. (2019a, September 9). Why our relationship with technology is destroying the planet. New Statesman. https://www.newstatesman.com/politics/environment/2019/09/why-ourrelationship-technology-destroying-planet

Wendland A.J. (2019b). Heidegger's new beginning: History, technology, and National Socialism'. In A.J. Wendland, C. Merwin, \& C. Hadjioannou (Eds.), Heidegger on technology (pp.149-173). New York: Routledge.

Wendland, A.J., Merwin C. \& Hadiioannou C. (Eds.). (2019). Heidegger on technology. New York: Routledge.

Young, J. (2002). Heidegger's later philosophy. Cambridge: Cambridge University Press.

Zimmerman, M. (2019). How pertinent is Heidegger's thinking for deep ecology? In. A.J. Wendland, C. Merwin, \& C. Hadjioannou (Eds.), Wendland, Merwin, Hadjioannou. Heidegger on technology (pp.209-225). New York, Routledge.

Department of Philosophy

King's College London

33 Surrey Street

London

WC2R $2^{\mathrm{ND}}$

United Kingdom

Email: aaron.wendland@kcl.ac.uk 